\title{
OPEN
}

Published online: 06 November 2019

\section{Author Correction: Novel Imidazole and Methoxybenzylamine Growth Inhibitors Affecting Salmonella Cell Envelope Integrity and its Persistence in Chickens}

\author{
Loïc Deblais, Yosra A. Helmy, Dipak Kathayat, Huang-chi Huang, Sally A. Miller \& \\ Gireesh Rajashekara
}

Correction to: Scientific Reports https://doi.org/10.1038/s41598-018-31249-0, published online 06 September 2018

The original version of this Article contained a typographical error in the spelling of the author Dipak Kathayat, which was incorrectly given as Diapak Kathayat. This error has now been corrected in the PDF and HTML versions of the paper, and in the accompanying supplementary material.

\begin{abstract}
(c) Open Access This article is licensed under a Creative Commons Attribution 4.0 International (c) License, which permits use, sharing, adaptation, distribution and reproduction in any medium or format, as long as you give appropriate credit to the original author(s) and the source, provide a link to the Creative Commons license, and indicate if changes were made. The images or other third party material in this article are included in the article's Creative Commons license, unless indicated otherwise in a credit line to the material. If material is not included in the article's Creative Commons license and your intended use is not permitted by statutory regulation or exceeds the permitted use, you will need to obtain permission directly from the copyright holder. To view a copy of this license, visit http://creativecommons.org/licenses/by/4.0/.
\end{abstract}

(C) The Author(s) 2019 